\title{
Implementation of the Physical Education, Sport and Health Learning Process Based on the 2013 Curriculum in Elementary Schools of Padang
}

\author{
Putri Annisa Ibnus*, Madri M \\ Faculty of Sport Science \\ Universitas Negeri Padang \\ Padang, Indonesia \\ putriannisaibnus99@gmail.com
}

\begin{abstract}
The purpose of this study is to find out how physical education, sports and health teachers in the Public Elementary Schools in Pauh District, Padang City in planning, implementing and evaluating learning activities according to the 2013 curriculum. This research is qualitative. The population of this research is physical education, sports, and health teachers in Public Elementary Schools in Pauh Subdistrict, Padang City, registered in the academic year 2017/2018, who implemented the 2013 Curriculum totaling ten people. The sampling technique of this study was total sampling. The instrument for obtaining data is observation and documentation. Learning planning is done by the teacher by preparing lesson plans, syllabus, mastering teaching materials, and supplementing teaching materials such as books. However, some teachers use lesson plans in the previous school year by updating the delivery method and not deviating from the curriculum. In the use of physical education, teacher strategy is still fixated with the commonly used methods of lecturing and practice. Evaluation of Learning Activities is carried out by Physical Education teachers in public elementary schools throughout Pauh, Padang, by preparing KI and KD in advance in the RPP. The assessment uses three predetermined aspects, namely, attitudes, knowledge, and skills.
\end{abstract}

Keywords - 2013 curriculum, teaching and learning process

\section{INTRODUCTION}

"PE part in overall subjects taught in school and cannot be separated from the other education. Learning outcomes of Physical Education Sports Health (Penjas Orchestra) is expected to provide an opportunity for students directly involved in the process of learning through physical activity"[1]. In connection with the implementation of the learning process $\mathrm{PE}$ present moment, which has been referred to the curriculum in 2013.

The process of learning to the curriculum in 2013 for all levels of education carried out by using a scientific approach (scientifik approach). In the learning process based on a scientific approach, the realm of attitudes, skills and knowledge. Within the scope of curriculum in 2013 in the learning process of physical education sport and health are Planning learning, execution of teaching and learning evaluation observe transformation of the substance or the teaching material that the students about "why, how, what" the end result is an increase and balance between the ability to be human good (soft skills), and people who have the skills and knowledge to live a decent (hard skills) of learners that includes aspects of competence attitudes, skills and knowledge. Curriculum 2013 emphasizes on modern pedagogic dimension of learning is to use a scientific approach. Scientific approach. The scientific approach to learning as defined includes observing, ask, reason, gather information and communicate to all subjects. And within the scope of the curriculum in 2013 in the learning process of physical education and health sports are learning plan, the execution of the learning and evaluation.

Based on the grand tour conducted in several primary schools all Padang Pauh City District composed of teachers and students, showed that teachers Penjasorkes lack of understanding about the importance of various competencies required for teachers in support to his professionalism, especially in the learning process and the associated planning, control teaching materials, implementing the learning process $(\mathrm{PBM})$, create a learning atmosphere, and an evaluation of the results of PBM. Although the results are not representative of the grand tour represents the entire learning process sport Physical Education and Health (Penjasorkes) in the District Pauh desert town, but with the results of the grand tour signs that indicate less than optimal during this learning process.

Physical education is a process through sport activities which are designed and collated systematically to stimulate growth and development, improve the ability and skill, intelligence and character formation, as well as positive values and attitudes for each student in order to achieve educational goals. The purpose of learning the curriculum PJOK 2013 include: 1. Have kesadran about the importance of treating the body as a form of gratitude to God Almighty. 
2. Shows responsible behavior towards learning facilities and infrastructure maintenance. 3. Shows the polite behavior and telerasi during activity. 4. Can analyze and practice the movements are studied. "Concluded that the learning plan is the result of the decision making process rational thinking about the goals and specific learning objectives, namely the

circuit behavioral changes as well as activities that should be implemented as an effort of delivering these objectives by exploiting all potential and existing learning resources".[2]

"Lesson planning is an integral part of learning activities, there must be also planning the implementation of learning" [3].

Curriculum 2013 is more eager to highlight the new curriculum for the achievement of competence attitudes, knowledge and skills that might be summed up in hardskilldan soft skill competency. The third refers to the competence, in the implementation of learning was setup in such a way sehiggga what is the main purpose of learning can be achieved.

"Is the evaluation of activities to collect information about the workings of something that further information is used for the right solution in taking a decision"[4].

"Physical education is an integral part of the overall education through physical activities to develop the individual organically the purpose neuro muscular, intellectually and emotionally"[5]. "Educationjasmanai is a process through physical activity, which dirancag and arranged systematically to stimulate growth and development, improve the ability and physical skills, kecerdesan and the formation of character, and the values and positive for every citizen in order to achieve educational goals"[6]. "That the educational goals jasamani consists of four domains are: physical, psychomotor, affective, cognitive"[7].

\section{RESEARCH METHODOLOGY}

Research This uses a qualitative approach. According to Bogdan Taylor is qualitative research is a research procedure that uses descriptive data in the form of words or word of mouth from people and behaviors that can be observed"[8]. This research was conducted at the State Elementary School Padang Pauh Se District of the ten schools. In the month of January 2018.

Informants in this study are all teachers of Physical Education and Health Olahaga who teach in elementary sub- district of Padang Pauh Based Curriculum 2013 as many as seven (10) persons. The type of data in this study are primary data and secondary data. The data used in this study comes from penjasorkes teachers in public primary schools throughout the District Padang Pauh.

The instrument used in this study is in the form of observation and documentation. In this analysis model, three components: "data reduction, data presentation, and withdrawal conclusions or verification"[9].

\section{RESULTS AND DISCUSSION}

\section{Plan}

Plan learning activities is one of the important tasks of teachers in the learning process. So that the learning process canterkonsepsikan well, the teacher is required to prepare and formulate learning objectives clearly and unambiguously. At the time of the study in public elementary school teachers throughout the District Pauh desert town of observation investigators that in implementing the lesson plans of teachers already make RPP.

Lesson plans that teachers do physical exercise and health education in public elementary school throughout the District Pauh City field includes syllabi, lesson plans, mastery of teaching materials and teaching materials. In making the syllabus and lesson plans of teachers in primary schools throughout the District SD N Padang Pauh made through discussions in advance through KKGO. there teachers create, reduce, increase, and improve RPP before taught to students and in preparing lesson plans teachers adjust to the textbook learners.

Based on the findings obtained by researchers, there are teachers who use only penjasorkes old RPP to be taught next semester as long as it does not deviate from the curriculum and delivery methods to be repaired or refurbished. It shows most of the teachers are not creative in the development of the RPP, in the absence of the development of the subject matter. it can be affected by a lack of understanding of teachers to other materials that the teachers teach only material that he mastered it.

Teaching material is the knowledge, skills, and attitudes that must be mastered learners in order to meet the expected standards of competence. To achieve all this, the first thing to do is teacher must first master the teaching materials. Mastery of all teachers teaching materials penjasorkes agree that it is important because it will facilitate the teachers themselves to teach it to students. Mastery of teaching materials are also included important in planning learning activities, mastery of teaching materials was carried out by teachers penjasorkes at the time before implementing the learning is in the evening.

For teaching materials such as books every teacher penjasorkes says it is still trying to complete a book for Curriculum 2013. There was even a teacher penjasorkes are still using SBC book to cover the book.

\section{Implementation of Learning Activities}

Classroom management is a skill teachers to create and maintain an optimal learning conditions and return to optimal condition gangguan.Pengelolaan effective if there is a prerequisite for an effective learning process. Implementation of the learning activities of the management class visits conducted by penjasorkes teacher in elementary school in the district of Padang Pauh, the teacher was able to conduct effective management of the class. Provide motivation, advice and warning at the time the learner made a mistake or learners do positive things, this will have an impact on the creation of the learning environment to the optimum.

The weakness of teachers in public primary schools in the district of Padang Pauh contained in the use of learning strategies. More teachers tend to use methods of 
practice and lecture only. This is a common method used by teacherspenjasorkes, while learning methods vary greatly. It is feared will be able to make the students bored in learning. Teachers should be able to vary the teaching methods. It can be influenced by a book that is very limited and the absence of a model or example that can be used as a reference by teachers in developing the strategy.

Penjasorkes Elementary School teacher in elementary school in the district of Padang Pauh also describe as the teacher Penjasorkes, we are required to be able to create interaction between learners and teachers as well as learners with learners. This can be done by providing diksusi to learners, frequently asked questions and provides an opportunity for learners to demonstrate after it was commented on by other students.

The importance of the role of media in learning can be seen from the growing evidence that media use tehadap positive impact of learning activities. This can happen if the media is prepared in accordance with the teaching materials. Aakan However, use of the media for at most schools are still an obstacle. Limited sports facilities that the school had had its own disadvantages, for example, the learning process is less able to walk properly because theory alone does not guarantee the achievement of learning goals. Teacher penjasorkes explained penjasorkes teachers are required to be more creative in addressing the shortage of facilities and infrastructure, not to teach learning materials are not only for reasons of inadequate facilities and infrastructure. With a shortage of these facilities we (teacherspenjasorkes) could provoke creativity of learners to modify the exercise device.

\section{Evaluation Activities}

Evaluations conducted by public school teachers throughout the District penjasorkes Padang Pauh prepared in accordance with $\mathrm{KI}$ and $\mathrm{KD}$ are predetermined in the RPP. KI and KD were obtained from the syllabus and curriculum. Evaluation collated based on three aspects of the assessment based on the curriculum of 2013. penjasorkes some teachers who teach in public school throughout the District Padang Pauh third musty all apply that judgment. Some are still using assessment aspects of the SBC is still using SK and KD.

The third assessment should be done because it has the function and role of each. For example, the assessment, the assessment used to assess learners' daily lives to the environment, courtesy of the older and mutual respect among friends. Assessment of knowledge serves to assess the extent to which learners in understanding and absorbing materials provided. As for the skills of learners practicing the function see material that has been taught.

At the beginning of the new academic year, the respondents always notify learner assessment criteria and minimum completeness criteria (KKM). This is useful for motivating the students to work hard in every learning because they know the standards to which they must value. With so learning in primary schools throughout the
District Padang Pauh lasted seriously and spirit of learners.

Penjasorkes latter involves the ability to perform a remedial teacher. All respondents argued that remedial action is very important because in addition to fixing the value remedial learners unfinished, proficiency level activity is also useful to make the students better understand the material taught.

\section{CONCLUSIONS}

Based on the results of research in the District Elementary School se Padang Pauh, obtained some conclusions as follows

1. Planning of learning activities carried out by teachers to prepare lesson plans, syllabi, teaching materials and complementary master teaching materials such as books. RPP and syllabus prepared by the teacher in KKGO activities carried out each month. But there are some teachers who use RPP previous academic year to renew the method of delivery and does not deviate from the curriculum. mastery of teaching materials is always done before the study because it is vital that the implementation of le'arning will be able to run well. To issue books according to the curriculum in 2013, elementary school teachers in the State penjasorkes se Padang PauhSubdistrict still shortcomings and try to complete it, as a result of the shortage of teachers using the curriculum guide for teaching. Implementation of the activities carried out by teacherspenjasorkes learning with classroom management, learning strategies and the use of teaching media. Penjasorkes teachers for classroom management in Se-State Elementary School District of Padang Pauh create a conducive learning atmosphere that is by giving warning, advice and praise to the behavior of learners. In the use of strategies teachers penjasorkes still transfixed by a method commonly used is lectures and practice. It will have an impact on the boredom of learners in the learning process. Pengguanaan teaching adapted to the media owned by the school, but to meet the shortage of teachers means penjasorkes modification sports equipment, because it is important to support the achievement of learning goals.

2. Evaluation of Learning Activities carried out by teachers in public elementary school penjasorkes Se- District of Padang Pauh by preparing beforehand $\mathrm{KI}$ and $\mathrm{KD}$ is in the RPP. assessment using the three aspects that have been determined; that is the attitude, knowledge and skills. But there are still teachers penjasorkes use aspect of the assessment is based SBC namely cognitive, affective and psychomotor. The assessment criteria and the KKM always delivered at the beginning of the semester by penjasorkes and perform remedial teacher for students who did not complete.

Based on the conclusions suggested maa: 1) for researchers, to increase knowledge and adds greater 
insight into the performance of which must be implemented by teacherspenjasorkes and in accordance with the demands of the curriculum. 2) for school institutions, agencies are expected to be better equip schools involved with the learning needs penjasorkes like, books, facilities and infrastructure, 3) for teachers, teachers are expected to prepare for the implementation of learning better. In terms of the preparation of lesson plans, learning method and others.So as to achieve maximum learning. Besides teachers penjasorkes State Primary School sub-district Pauh Padang also expected kept up-to customize learning what is demanded by the curriculum in 2013, 4) for educational institutions, the educational institutions are expected this thesis can be used as additives reading in the library that can be developed by parties to broaden the reader to increase knowledge about the learning process of physical education and health based on the curriculum of 2013, 5) for further research, to further research is expected to be able to do research on teaching and learning of physical education and health based curriculum in 2013 can different designs.

\section{REFERENCES}

[1] A. Asmi, H. Neldi and Khairuddin, "Meningkatkan Minat Belajar Siswa dalam Pembelajaran Pendidikan Jasmani Olahraga dan Kesehatan melalui Metode Bermain pada Kelas viii-4Sekolah Menengah Pertama Negeri 2 Batusangkar," J. Menssana, Vol.3, no.1, pp, 33-44. Mey. 2018.

[2] Wina Sanjaya, "Perencanaan dan Desain Sistem Pembelajaran," Jakarta; Kencana Prenada Media Group. 2008, pp, 78-90.

[3] Fadillah, "Implementasi Kurikulum 2013," Yogyakarta; Ar-Rozz Media. 2014.

[4] Mulyasa, E, "Pengembangan dan Implementasi Kurikulum,” Bandung; Remaja Roskarya. 2013, pp, 67-77.

[5] Guntur, "Peranan Pendekatan Andragogis dalam Pembelajaran Pendidikan Jasmani," J. Pendidikan Jasmani Indonesia, Vol. 6, No.2, Agust. 2009.

[6] Nurhadi Santoso, "Pendidikan Jasmnai disekolah Menengah Atas;Antara Harapan dan Kenyataan," J. Pendidikan Jasmani Indonesia, Vol.6, No.2, August. 2009

[7] Sukintaka, "Teori Penelitian Jasmani," Solo; ESA Grafik. 2001, pp, 88-92.

[8] Sugiyono. "Metodologi Penelitian Pendidikan Pendekatan Kuantitatif, Kualitatif dan R\&D," Bandung; Alfabeta. 2011, pp, 76- 96.

[9] Sugito, Adi Warsito, "Materi Pelatihan Guru Implementasi Kurikulum 2013,” Jakarta; Kemendikbud. 2015. 